\title{
CARD1 5 gene polymorphisms in patients with spondyloarthropathies identify a specific phenotype previously related to Crohn's disease
}

\author{
D Laukens*, H Peeters*, D Marichal, B Vander Cruyssen, H Mielants, D Elewaut, \\ P Demetter, C Cuvelier, M Van Den Berghe, P Rottiers, E M Veys, E Remaut, L Steidler, \\ F De Keyser, M De Vos
}

See end of article for authors' affiliations

Correspondence to: Dr Harald Peeters, Department of Gastroenterology, Ghent University Hospital, De Pintelaan 185, B-9000 Ghent, Belgium; harald peeters@UGent.be

*These authors made an equal contribution to the work

Accepted

9 November 2004

Published Online First

11 November 2004

Background: The association between spondyloarthropathy and Crohn's disease is well known. A risk for evolution to Crohn's disease has already been shown in the subgroup of patients with spondyloarthropathy associated with chronic gut inflammation.

Objective: To investigate whether the reported polymorphisms in the CARD15 gene, a susceptibility gene for Crohn's disease, are associated with the presence of preclinical intestinal inflammation observed in spondyloarthropathies.

Methods: 104 patients with spondyloarthropathies were studied. All underwent ileocolonoscopy with biopsies between 1983 and 2004. The prevalence of three single nucleotide polymorphisms in the CARD15 gene (R702W, G908R, and 1007fs) was assessed using restriction fragment length polymorphism-polymerase chain reaction (RFLP-PCR); the patients were compared with an ethnically matched Crohn's disease population and a control population.

Results: The carrier frequency of R702W, G908R, or 1007fs variants in the spondyloarthropathy populations $(20 \%)$ was similar to the control population (17\%), but increased to $38 \%$ in the spondyloarthropathy subgroup with chronic gut inflammation. This frequency was significantly higher than in the other spondyloarthropathy subgroups $(p=0.001)$ or the control group $(p=0.006)$, but not different from the Crohn's disease group (49\%) (NS). This indicates that CARD15 polymorphisms are associated with a higher risk for development of chronic gut inflammation.

Conclusions: CARD15 gene polymorphisms clearly identify a subgroup of patients with spondyloarthropathies associated with chronic intestinal inflammation.

$\mathrm{T}$ he spondyloarthropathies are a group of interrelated inflammatory diseases characterised by a pauciarticular, peripheral, asymmetrical arthritis with or without axial involvement, with ankylosing spondylitis as the prototype. Reported prevalences of spondyloarthropathy vary between $0.2 \%$ and $1.9 \% .^{23}$ Although an association with HLA-B27 is strong, recent genetic studies suggest a polygenic model of susceptibility. ${ }^{4-7}$

In up to $60 \%$ of spondyloarthropathy patients, articular involvement is associated with subclinical histological evidence of chronic or acute gut inflammation in the ileum or colon. ${ }^{8-10}$ We described a long term evolution to overt Crohn's disease in $13 \%$ of patients with initial chronic gut inflammation. ${ }^{11}{ }^{12}$ The presence of chronic intestinal inflammation was not related to HLA-B27, but a weak association with HLAB62 was found. ${ }^{11}$

The observed immunological similarities between spondyloarthropathy with gut inflammation and Crohn's disease support the concept that this subgroup of spondyloarthropathy patients can be considered a model for early immune alterations related to Crohn's disease. An enrichment of gut mucosal $\mathrm{T}$ cell lines with $\alpha \mathrm{E} \beta 7$ integrin and an increased expression of its ligand, E-cadherin, is found in the intestine in Crohn's disease as well as in spondyloarthropathy patients. ${ }^{13-15}$ Recirculation of gut primed $\mathrm{T}$ cells to synovial tissue is one potential mechanism whereby gut and synovial inflammation could be linked. This hypothesis is supported by an altered expression of $\beta 7$ integrins, which are highly expressed within the gut, on synovial $\mathrm{T}$ cells from patients with spondyloarthropathies compared with rheumatoid arthritis. ${ }^{16}$ Another potential mechanism includes trafficking of antigen presenting cells between gut and joints. Consistent with this was the augmented infiltration of gut mucosa and synovium with CDl63 positive macrophages (producing interleukin 1 (ILl) and tumour necrosis factor $\alpha$ (TNF $\alpha$ ) in both Crohn's disease and spondyloarthropathy. ${ }^{17}{ }^{18}$ Finally, a comparable beneficial clinical effect of infliximab, a monoclonal antibody to $\mathrm{TNF} \alpha$, suggests a key role for this cytokine in both diseases. ${ }^{19} 20$

In 2001, a correlation was reported between polymorphisms in the CARD15 gene and an increased susceptibility to Crohn's disease. ${ }^{21-23}$ Three independent single nucleotide polymorphisms (SNPs) in CARD15 are associated with Crohn's disease in around 30-46\% of patients (one frame shift mutation (1007fs (SNP13)) and two missense mutations (R702W (SNP8) and G908R (SNP12)). ${ }^{22}{ }^{24}$ These variants increase the risk for Crohn's disease by a factor of 3 for heterozygotes and by a factor of 38 or 44 for, respectively, homozygous or compound heterozygous individuals. ${ }^{22}$ Lower prevalences have been described in Crohn's disease patients in Scotland, Ireland, and northern Europe, whereas no association could be found in Japan. ${ }^{25-28}$

The CARD15 gene encodes for an intracellular protein, which is expressed in monocytes, granulocytes, and dendritic, epithelial, and Paneth cells, and has binding affinity for

Abbreviations: CARD, caspase recruitment domain; ESSG, European Spondylarthropathy Study Group; SNP, single nucleotide polymorphism 
bacterial cell wall components such as muramyldipeptides. ${ }^{29}$ The CARD15 protein is involved in NFKB activation and in apoptosis by two $\mathrm{N}$-terminal caspase recruitment domains (hence the term CARD), although its precise pathogenic role in Crohn's disease remains to be determined. ${ }^{29-31}$

CARD15 gene polymorphisms have also been linked to another related disorder, Blau's syndrome, characterised by granulomatous inflammation of the uvea, skin, and joints. ${ }^{32}$

Several studies have been carried out to investigate the role of CARD15 polymorphisms in spondyloarthropathies. These studies did not show an association with spondyloarthropathies or ankylosing spondylitis in particular. ${ }^{33-37}$ An increased prevalence of CARD15 polymorphisms was found in psoriatic arthritis though not in psoriatic skin disease. ${ }^{38-40}$ However, a recent Italian study could not confirm this association. ${ }^{41}$ Nevertheless, this finding could emphasise the importance of investigating the possible role of these genetic variants in specific clinical subpopulations of patients. In Crohn's disease, CARD15 polymorphisms also seem to be related to certain clinical phenotypes. ${ }^{42-46}$

In view of the apparent correlation between gut inflammation in spondyloarthropathies and their clinical evolution to Crohn's disease, we investigated whether the presence of polymorphisms in this susceptibility gene for Crohn's disease is associated with gut inflammation in spondyloarthropathy.

\section{METHODS}

\section{Study population}

This study included 104 white patients with spondyloarthropathies (according to the ESSG criteria ${ }^{47}$ ), who underwent an ileocolonoscopy with concomitant ileal and colonic biopsies between 1983 and 2004. This population consisted of 74 male and 30 female patients with a mean age of 46 years (range 21 to 77). Spondyloarthropathy patients were systematically referred by the rheumatologist for an ileocolonoscopy with biopsies, independent of the presence of gastrointestinal symptoms.

Patients with a diagnosis of clinical Crohn's disease or psoriasis before the diagnosis of spondyloarthropathy were excluded from the study.

A subgroup of 54 patients with long term follow up since the time of their diagnosis of spondyloarthropathy (ranging from 17 to 49 years) was recently clinically reassessed. New follow up colonoscopies were not carried out.

The total spondyloarthropathy population consisted of 75 patients with ankylosing spondylitis according to the modified New York criteria ${ }^{48}$ and 29 with an undifferentiated

Table 1 Prevalence of CARD15 variants in the populations according to subtypes defined at baseline

\begin{tabular}{|c|c|c|}
\hline & n & $\begin{array}{l}\text { Carriers of } \\
\text { CARD15 } \\
\text { variant(s) }\end{array}$ \\
\hline \multicolumn{3}{|l|}{ Classification } \\
\hline Controls & 140 & $24(17 \%)$ \\
\hline Crohn's disease & 156 & $77(49 \%)^{*}$ \\
\hline Spondyloarthropathy & 104 & $21(20 \%) \dagger$ \\
\hline Ankylosing spondylitis & 75 & $16(21 \%)$ \\
\hline Undifferentiated spondyloarthropathies & 29 & $5(17 \%)$ \\
\hline \multicolumn{3}{|c|}{ Gut histology in the spondyloarthropathy population } \\
\hline Chronic inflammation & $40(38 \%)$ & $15(38 \%) \ddagger$ \\
\hline Acute inflammation & $24(23 \%)$ & $0(0 \%)$ \\
\hline Normal histology & $40(38 \%)$ & $6(15 \%)$ \\
\hline \multicolumn{3}{|c|}{ 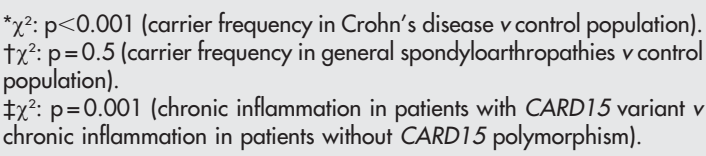 } \\
\hline
\end{tabular}

form of spondyloarthropathy. Eighteen patients with ankylosing spondylitis had only axial involvement, while 57 also had peripheral disease (defined as the history or presence of peripheral arthritis, enthesitis, or both). Twenty five patients with undifferentiated spondyloarthropathy had peripheral disease and four only had axial involvement. These four patients had inflammatory low back pain and fulfilled the ESSG criteria but not the modified New York criteria for ankylosing spondylitis.

HLA-B27 status was known in 81 patients. In 53 patients both HLA-B27 and HLA-B62 status was known.

A population of 156 consecutive patients with Crohn's disease proven on clinical, endoscopic, and histological grounds was also included. This cohort included 57 male and 99 female patients with a mean age of 38 years (range 18 to 80). Prevalences were also compared with those in a control population of 140 individuals.

The study was approved by the local ethics committee. All patients signed their informed consent.

\section{Histological classification}

A classification of histological lesions was used as reported in previous studies. ${ }^{811} 124950$ Three subgroups were distinguished: patients with normal gut histology, and those with acute and chronic inflammation. ${ }^{51}$

In acute inflammatory lesions normal architecture was well preserved. A mucosal and epithelial infiltrate of neutrophils and eosinophils was present, without a significant increase in lymphocytes. Small superficial ulcers covered with fibrin and neutrophils overlying hyperplastic lymphoid follicles were occasionally observed. The lamina propria was oedematous and haemorrhagic and contained mainly polymorphonuclear cells. The pattern of inflammation was similar to that seen in acute self limiting bacterial enterocolitis.

The principal features of chronic inflammatory lesions were mucosal architectural alterations with crypt distortion and atrophy in the colon, and villous blunting and fusion in ileal mucosa. In both ileum and colon there was an increased mixed cellularity and formation of basal lymphoid aggregates in the lamina propria. Whenever one of several biopsies featured chronic lesions, regardless of acute or active inflammation in other fragments, a diagnosis of chronic inflammation was made.

Although non-steroidal anti-inflammatory drugs may induce intestinal disorders, we and others excluded these drugs as factors in the aetiology of reported chronic inflammation. ${ }^{8} 1052$

\section{CARD 15 genotyping (R702W, G908R, and 1007fs),} and HLA-B27 and HLA-B62 typing

Genomic DNA was extracted from whole blood using the Qiagen blood and cell culture DNA kit (Westburg BV, Leusden, Netherlands). All patients were genotyped for R702W, G908R, and 1007fs using restriction fragment length polymorphism-polymerase chain reaction (RFLP-PCR), followed by separation of the DNA fragments on a $2.5 \%$ agarose gel. The missense mutation R702W (GenBank accession number G67950) abolishes the restriction site for MspI, resulting in an intact 130 base pair (bp) band for mutant alleles compared with two bands of 54 and 76 bp for wild type alleles (forward primer: 5'-CAGCCCTGATGACATTT CTCTT-3'; reverse primer: 5'-AGCCGCTCCTCCTGCATCTCG TA-3'). The missense mutation G908R (GenBank accession number G67951) creates a restriction site for HinP1l. The frameshift mutation 1007fs (GenBank accession number G67955) creates a restriction site for NlaIV. The presence of a mutant allele results in two bands of 219 and $41 \mathrm{bp}$, while the wild type allele produces a single $260 \mathrm{bp}$ product (forward 
Table 2 Carrier frequency of CARD15 variants in patients with spondyloarthropathies, Crohn's disease, and controls (\%)

\begin{tabular}{|c|c|c|c|c|c|c|c|c|c|c|c|c|}
\hline & \multicolumn{4}{|c|}{ Spondyloarthropathy (n= 104) } & \multicolumn{4}{|c|}{ Crohn's disease $(n=156)$} & \multicolumn{4}{|c|}{ Controls $(n=140)$} \\
\hline & R702W & G908R & $1007 \mathrm{fs}$ & Overall* & R702W & G908R & $1007 \mathrm{fs}$ & Overall* & R702W & G908R & $1007 \mathrm{fs}$ & Overall* \\
\hline $\begin{array}{l}\text { CARD } 15^{-/+} \\
\text {CARD } 15^{-/-}\end{array}$ & $\begin{array}{l}12(12) \\
0(0)\end{array}$ & $\begin{array}{l}4(4) \\
0(0)\end{array}$ & $\begin{array}{l}4(4) \\
1(1)\end{array}$ & $21(20)$ & $\begin{array}{l}39(25) \\
4(3)\end{array}$ & $\begin{array}{l}11(7) \\
3(2)\end{array}$ & $\begin{array}{l}27(17) \\
0(0)\end{array}$ & 77 (49) & $\begin{array}{l}18(13) \\
0(0)\end{array}$ & $\begin{array}{ll}1 & (1) \\
0 & (0)\end{array}$ & $\begin{array}{l}6(4) \\
0(0)\end{array}$ & $24(17)$ \\
\hline
\end{tabular}

Data are numbers of patients carrying R702W, G908R or $1007 \mathrm{fs}$ variants. CARD 15 $5^{-1+}$, heterozygous; CARD15 $/-$, homozygous.

Overall, total number of patients in the group carrying at least one variant

*The sum of all allelic CARD15 variants is greater than the overall number of patients carrying at least one variant, as some patients carry two different single nucleotide polymorphisms, thus displaying compound heterozygous status.

primer: 5'-CTGAGCCTTTGTTGATGAGC-3'; reverse primer: 5'-TCTTCCAACCACATCCCCATT-3').

In the patients with known HLA-B27 and HLA-B62 status, typing of these markers was done using the microlymphocytotoxity test, according to Terasaki and McClelland..$^{53}$

\section{Statistical analysis}

Statistical significance was determined by the $\chi^{2}$ test and odds ratios using SPSS (SPSS Inc, Chicago, Illinois, USA). Multivariate analysis (logistic regression) was carried out to investigate whether an association found in univariate analysis was independent of other genetic markers. Probability (p) values of less than 0.05 were considered significant.

\section{RESULTS}

We subdivided our cohort into three groups according to gut histology. Forty patients (38\%) had normal histology, 24 $(23 \%)$ had acute gut inflammation, and $40(38 \%)$ had chronic gut inflammation (table 1).

\section{Univariate analysis \\ Prevalence of CARD 15 polymorphisms in the various populations}

The prevalences of CARD15 polymorphisms in the total spondyloarthropathy $(20 \%)$, specific ankylosing spondylitis $(21 \%)$, and undifferentiated spondyloarthropathy (17\%) populations did not differ significantly (table 1). All except one (homozygous for the $1007 \mathrm{fs}$ allelic variant) were heterozygous for at least one mutation. The prevalences of R702W, G908R, and 1007fs allelic variants in these spondyloarthropathy populations were $12 \%, 4 \%$, and $5 \%$ respectively

Table 3 Prevalences of CARD15 polymorphisms according to the presence of mainly axial or peripheral involvement in the total spondyloarthropathy group $(n=104)$, the ankylosing spondylitis group $(n=75)$, and the undifferentiated spondyloarthropathy group $(n=29)$

\begin{tabular}{|c|c|c|c|c|}
\hline & \multicolumn{3}{|l|}{ CARD15 } & \\
\hline & Wild type & Variant & Total & \\
\hline \multicolumn{5}{|c|}{ Total spondyloarthropathy group } \\
\hline Axial & 22 & 0 & 22 & $p=0.006$ \\
\hline Peripheral & 61 & 21 & 82 & \\
\hline Total & 83 & 21 & 104 & \\
\hline \multicolumn{5}{|c|}{ Ankylosing spondylitis group } \\
\hline Axiál & 18 & 0 & 18 & $p=0.006$ \\
\hline Peripheral & 41 & 16 & 57 & \\
\hline Total & 59 & 16 & 75 & \\
\hline \multicolumn{5}{|c|}{ Undifferentiated spondyloarthropathy group } \\
\hline Axial & 4 & 0 & 4 & $p=1.0$ \\
\hline Peripheral & 20 & 5 & 25 & \\
\hline Total & 24 & 5 & 29 & \\
\hline
\end{tabular}

(table 2). No compound heterozygosity was found. All carriers of CARD15 polymorphisms in the spondyloarthropathy group had (a history of) peripheral disease (table 3). There were no significant differences in disease duration or the duration of the follow up period between the spondyloarthropathy patients carrying CARD 15 polymorphisms and the patients without these polymorphisms (data not shown).

In the Crohn's disease population, a carrier frequency of $49 \%$ (77 of 156 patients) was observed (table 1). Forty three Crohn's disease patients carried at least one R702W polymorphism, 14 carried at least one G908R polymorphism, and 27 carried at least one 1007fs polymorphism. Fourteen patients carried two polymorphisms, of which seven were homozygous and seven were compound heterozygous (table 2).

In the control group, 24 individuals (17\%) carried CARD15 polymorphisms (table 1). All except one (compound heterozygous for the R702W and 1007fs variant) were single heterozygotes (table 2).

The prevalence of polymorphisms in the spondyloarthropathy cohort (20\%) was not different from that in the control group $(17 \%) \quad(p=0.5$; odds ratio $(\mathrm{OR})=1.22$ (95\% confidence interval (CI), 0.64 to 2.34)) and significantly lower than in our Crohn's disease population $(49 \%) \quad(\mathrm{p}<0.001$; $\mathrm{OR}=3.85(95 \% \mathrm{CI}, 2.17$ to 6.83$))$.

\section{Association between CARD 15 polymorphisms and intestinal inflammation in spondyloarthropathy patients}

The carrier frequency in the subpopulation of spondyloarthropathy patients with chronic gut inflammation was 38\% ( 15 of 40 patients) which was significantly higher than in the control population $(\mathrm{p}=0.006 ; \mathrm{OR}=2.9(95 \% \mathrm{CI}, 1.33$ to $6.30)$ ) or the other spondyloarthropathy populations $(\mathrm{p}=0.001 ; \mathrm{OR}=5.80(2.02$ to 16.68$))$ and not statistically different from that in our Crohn's disease population $(49 \%$, $\mathrm{p}=0.2 ; \mathrm{OR}=1.62(0.80$ to 3.31$))($ table 1$)$.

Of all spondyloarthropathy patients carrying CARD15 polymorphisms, $71 \%$ ( 15 of 21 patients) had chronic gut inflammation, none had acute inflammation, and 29\% had normal histology (table 1). The only spondyloarthropathy patient carrying two CARD15 variants also had chronic gut inflammation. In contrast, only 25 of 83 patients with a wild type genotype (30\%) had chronic gut inflammation, 29\% had acute inflammation, and $41 \%$ had normal histology. Consequently, the presence of CARD15 polymorphisms was associated with a higher risk of the development of chronic gut inflammation.

There were no significant differences between the ankylosing spondylitis and the undifferentiated spondyloarthropathy groups for the prevalence of CARD15 polymorphisms in patients with normal gut $(3 / 29 \vee 3 / 11$, respectively; $\mathrm{p}=0.3$; $\mathrm{OR}=3.3(95 \% \mathrm{CI}, 0.5$ to 19.4$))$, acute gut inflammation $(0 / 13$ $v 0 / 11)$, or chronic gut inflammation $(13 / 33 v 2 / 7 ; \mathrm{p}=0.7$; $\mathrm{OR}=1.6$ (95\% CI, 0.3 to 9.7$)$ ). 
In the subgroup of 54 patients who were clinically reassessed, four had evolved from histological chronic gut inflammation towards clinically overt Crohn's disease. Two of these four patients carried CARD15 polymorphisms. The other 22 patients with chronic gut inflammation in this group did not develop clinical Crohn's disease.

\section{Association between CARD 15 polymorphisms and HLA-B27in spondyloarthropathy patients}

There was no significant association between the presence of these two genetic markers. Six of 34 HLA-B27 negative patients carried CARD15 polymorphisms $v 13$ of 47 HLA-B27 positive patients $(\mathrm{p}=0.3$; $\mathrm{OR}=1.8(95 \% \mathrm{CI}, 0.6$ to 5.3$)$ ).

\section{Multivariate analysis}

In the subgroup of 53 spondyloarthropathy patients in whom both HLA-B27 and HLA-B62 status was known, logistic regression was undertaken (with the presence of chronic gut inflammation as the dependent variable). This showed that the association between chronic gut inflammation and CARD15 polymorphisms ( $\mathrm{p}=0.01$; OR $=17.3$ (95\% CI, 2.0 to 152.3$)$ ) was independent of HLA-B27 $(\mathrm{p}=0.42 ; \mathrm{OR}=1.7$ $(0.5$ to 6.0$))$ and HLA-B62 $(\mathrm{p}=0.28$; OR $=2.5(0.5$ to 13.0$))$.

\section{DISCUSSION}

In this study we describe a novel and remarkably strong association between variants in a host defence gene located on chromosome 16 (CARD15) and a chronic form of gut inflammation in patients with spondyloarthropathies. The prevalence of CARD15 polymorphisms in this subgroup of spondyloarthropathy patients was not significantly different from that seen in patients with Crohn's disease.

Three single nucleotide polymorphisms have been associated with Crohn's disease. ${ }^{21-23}$ One variant (1007fs) encodes a truncated protein which results in altered activation of NFKB in response to bacterial stimuli. ${ }^{29-31}$ The two other single nucleotide polymorphisms (R702W and G908R) result in an amino acid substitution.

More recently, several groups assessed the linkage of CARD15 variants in Crohn's disease to particular clinical phenotypes, but the results of these retrospective studies are disparate. The presence of two mutations has been linked to younger age at onset and preferential involvement of small bowel. ${ }^{43}$ Preference for ileal involvement was also reported by Cuthbert et $a l^{42}$ and by Ahmad et al. ${ }^{44}$ Fibrostenosing disease was the dominant type in a study by Abreu et al. ${ }^{45}$ In these studies, no association of CARD15 variants with extraintestinal involvement could be shown.

Our study shows a new association between these three Crohn's disease associated variants in the leucine-rich region of the CARD15 gene and a distinct subpopulation of patients with spondyloarthropathies. As in previous reports, the overall prevalence of mutations in spondyloarthropathy patients was not statistically different from the prevalence in our control population. ${ }^{33-37}$ However, unlike the previous studies, we identified a distinct clinical subgroup-characterised by the presence of chronic inflammatory gut lesionswith a high prevalence of CARD15 polymorphisms similar to the Crohn's disease population and significantly higher than in the control population or the other spondyloarthropathy patients. Previous studies from our group showed that these patients with chronic gut inflammation were at particular risk for progression to Crohn's disease. ${ }^{11}{ }^{12}$

Strikingly, in the present study none of the spondyloarthropathy patients with only axial disease carried CARD15 polymorphisms. Carriers of these polymorphisms all had (a history of) peripheral disease. This is in accord with previous studies of patients with ankylosing spondylitis where more chronic gut inflammation could be found in those with peripheral disease than in those with strict axial disease. ${ }^{11}$

One previous study investigated CARD15 polymorphisms in patients with ankylosing spondylitis, Crohn's disease, and ulcerative colitis. ${ }^{54}$ It did not show a higher prevalence of CARD15 variants in patients with ankylosing spondylitis plus Crohn's disease compared with idiopathic ankylosing spondylitis, ankylosing spondylitis plus ulcerative colitis, or healthy controls. However, the low prevalence of CARD15 variants in the Crohn's disease population with ankylosing spondylitis was not compared with the prevalence in a general Crohn's disease population and it unexpectedly revealed a possible association between the G908R CARD15 variant and ankylosing spondylitis plus ulcerative colitis.

Moreover, in a recent study we found an association between CARD15 polymorphisms and the presence of radiological sacroiliitis in Crohn's disease patients, unrelated to the HLA-B27 status of these subjects. These data already suggested a role for the CARD15 gene in the link between gut and joint inflammation. ${ }^{46}$

Our findings confirm the previous reported clinical, therapeutic, and immunological links between spondyloarthropathies and Crohn's disease and provide genetic proof for the association between these two disorders. As chronic gut inflammation in the majority of spondyloarthropathy patients remains asymptomatic, this might suggest that CARD15 polymorphisms could be linked to the development of (subclinical) chronic gut inflammation rather than to Crohn's disease as such.

The underlying pathogenic mechanisms that could explain the phenotypic expression of CARD15 mutations in spondyloarthropathies need to be investigated. CARD15 encodes a cytosolic protein that could play a role in spondyloarthropathies by interference with transport of antigens by macrophages from mucosal surfaces to the joints. ${ }^{55}$ CARDI5 seems to function as an intracellular receptor for bacterial components, where the C-terminal leucine-rich repeat domain (LRR domain) is crucial for responsiveness. The cellular response to bacterial products has been shown to be altered in HEK293T cells transfected with expression plasmids containing any of the three SNPs. ${ }^{29} 31$ Moreover, expression of CARD15 in myeloblastic and epithelial cells is enhanced by proinflammatory cytokines and bacterial components, through $\mathrm{NF \kappa B} .{ }^{303156}$ This response is likely to mediate cytokine production including $\mathrm{TNF} \alpha$, suggesting that upregulation of CARD15 may be part of a positive regulatory loop and facilitate the response of the host to pathogens. A genetically determined disturbance of handling of bacterial products in the intestinal tract, leading to altered transport of antigens by macrophages to synovial tissue, is an interesting hypothesis that should be investigated in spondyloarthropathy. A further identification and characterisation of inflammatory cells involved in gut and joint inflammation may also lead to new therapeutic targets.

\section{Conclusions}

A distinct phenotype associated with the three main Crohn's disease associated CARD15 variants is reported in patients with spondyloarthropathies. Our data show that the presence of CARD15 variants in spondyloarthropathy patients strongly predisposes to chronic intestinal inflammation, defining a population at risk for evolution to Crohn's disease. However, the persistence of the subclinical character of the inflammation in a large proportion of patients may reflect the fact that Crohn's disease is a multigeneic disease or alternatively that the heterozygous carriage of CARD15 polymorphisms predisposes only to subclinical inflammation. 


\section{ACKNOWLEDGEMENTS}

This study was supported by a concerted action grant GOA2001/ 12051501 of Ghent University, Belgium; by grants of the Flemish Society of Crohn and Ulcerative Colitis, the Flemish Society of Gastroenterology, and the Flanders Interuniversity Institute for Biotechnology (VIB).

\section{Authors' affiliations}

D Laukens, P Rottiers, E Remaut, Department of Molecular Biomedical Research, Ghent University and Flanders Interuniversity Institute for Biotechnology (VIB), Ghent, Belgium

H Peeters, D Marichal, M De Vos, Department of Gastroenterology, Ghent University Hospital

B Vander Cruyssen, H Mielants, D Elewaut, M Van Den Berghe,

E M Veys, F De Keyser, Department of Rheumatology, Ghent University Hospital

P Demetter, C Cuvelier, Department of Pathology, Ghent University Hospital

L Steidler, Alimentary Pharmabiotic Centre, University College Cork, Cork, Ireland

\section{REFERENCES}

1 Khan MA. Update on spondyloarthropathies. Ann Intern Med 2002; 136:896-907.

2 Lawrence RC, Helmick CG, Arnett FC, Deyo RA, Felson DT, Giannini EH, et al. Estimates of the prevalence of arthritis and selected musculoskeletal disorders in the United States. Arthritis Rheum 1998:41:778-99.

3 Braun J, Bollow M, Remlinger G, Eggens U, Rudwaleit M, Distler A, et al. Prevalence of spondylarthropathies in HLA-B27 positive and negative blood donors. Arthritis Rheum 1998;41:58-67.

4 Reveille JD, Ball EJ, Khan MA. HLA-B27 and genetic predisposing factors in spondyloarthropathies. Curr Opin Rheumatol $2001 ; 13: 265-72$.

5 Granfors K, Marker-Hermann E, de Keyser F, Khan MA, Veys EM, Yu DT. The cutting edge of spondylarthropathy research in the millennium. Arthritis Rheum 2002;46:606-13

6 Brown MA, Kennedy LG, MacGregor AJ, Darke C, Duncan E, Shafford JL, et al. Susceptibility to ankylosing spondylitis in twins: the role of genes, HLA, and the environment. Arthritis Rheum 1997;40:1823-8.

7 Said-Nahal R, Miceli-Richard C, Berthelot JM, Duche A, Dernis-Labous E, Le Blevec $G$, et al. The familial form of spondylarthropathy: a clinical study of 115 multiplex families. Groupe Francais d'Etude Genetique des Spondylarthropathies. Arthritis Rheum 2000;43:1356-65.

8 De Vos M, Cuvelier C, Mielants H, Veys E, Barbier F, Elewaut A lleocolonoscopy in seronegative spondylarthropathy. Gastroenterology 1989;96:339-44

9 Leirisalo-Repo M, Turunen U, Stenman S, Helenius P, Seppala K. High frequency of silent inflammatory bowel disease in spondylarthropathy. Arthritis Rheum 1994;37:23-31.

10 Simenon G, Van Gossum A, Adler M, Rickaert F, Appelboom T. Macroscopic and microscopic gut lesions in seronegative spondyloarthropathies. J Rheumatol 1990;17:1491-4.

11 Mielants H, Veys EM, Cuvelier C, De Vos M, Goemaere S, De Clercq L, et al. The evolution of spondyloarthropathies in relation to gut histology. II. Histological aspects. J Rheumatol 1995;22:2273-8.

12 De Vos M, Mielants H, Cuvelier C, Elewaut A, Veys E. Long-term evolution of gut inflammation in patients with spondyloarthropathy. Gastroenterology 1996;110:1696-703

13 Elewaut D, De Keyser F, Cuvelier C, Lazarovits Al, Mielants H, Verbruggen G, et al. Distinctive activated cellular subsets in colon from patients with Crohn's disease and ulcerative colitis. Scand J Gastroenterol 1998;33:743-8.

14 Demetter P, Baeten D, De Keyser F, De Vos M, Van Damme N, Verbruggen G, et al. Subclinical gut inflammation in spondyloarthropathy patients is associated with upregulation of the E-cadherin/catenin complex. Ann Rheum Dis 2000;59:21 1-16.

15 Demetter P, De Vos M, Van Damme N, Baeten D, Elewaut D, Vermeulen S, et al. Focal up-regulation of E-cadherin-catenin complex in inflamed bowel mucosa but reduced expression in ulcer-associated cell lineage. Am J Clin Pathol 2000;114:364-70.

16 Elewaut D, De Keyser F, Van Den Bosch F, Lazarovits Al, De Vos M, Cuvelier C, et al. Enrichment of T cells carrying beta7 integrins in inflamed synovial tissue from patients with early spondyloarthropathy, compared to rheumatoid arthritis. J Rheumatol 1998;25:1932-7.

17 Baeten D, Demetter P, Cuvelier CA, Kruithof E, Van Damme N, De Vos M, et al. Macrophages expressing the scavenger receptor CD163: a link between immune alterations of the gut and synovial inflammation in spondyloarthropathy. J Pathol 2002; 196:343-50.

18 Demetter P, De Vos M, Van Huysse JA, Baeten D, Ferdinande L, Peeters H, et al. Colon mucosa of both spondyloarthritis and Crohn's disease patients is enriched with macrophages expressing the scavenger receptor CD163. Ann Rheum Dis 2004, May 27 (Epub ahead of print).

19 Van Den Bosch F, Kruithof E, Baeten D, Herssens A, De Keyser F, Mielants H, et al. Randomized double-blind comparison of chimeric monoclonal antibody to tumor necrosis factor alpha (infliximab) versus placebo in active spondylarthropathy. Arthritis Rheum 2002;46:755-65.
20 Van Den Bosch F, Kruithof E, De Vos M, De Keyser F, Mielants H. Crohn's disease associated with spondyloarthropathy: effect of TNF-alpha blockade with infliximab on articular symptoms. Lancet 2000;356:1821-2.

21 Ogura Y, Bonen DK, Inohara N, Nicolae DL, Chen FF, Ramos R, et al. A frameshift mutation in NOD2 associated with susceptibility to Crohn's disease. Nature 2001;411:603-6.

22 Hugot JP, Chamaillard M, Zouali H, Lesage S, Cezard JP, Tysk C, et al. Association of NOD2 leucine-rich repeat variants with susceptibility to Crohn's disease. Nature 2001;411:599-603.

23 Hampe J, Cuthbert A, Croucher PJ, Mirza MM, Mascheretti S, Fisher S, et al. Association between insertion mutation in NOD2 gene and Crohn's disease in German and British populations. Lancet 2001;357:1925-8.

24 Esters N, Pierik M, van Steen K, Vermeire S, Claessens G, Joossens S, et al. Transmission of CARD15 (NOD2) variants within families of patients with inflammatory bowel disease. Am J Gastroenterol 2004;99:299-305.

25 Yamazaki K, Takazoe M, Tanaka T, Kazumori T, Nakamura Y. Absence of mutation in the NOD2/CARD15 gene among 483 Japanese patients with Crohn's disease. J Hum Genet 2002:47:469-72.

26 Inoue N, Tamura K, Kinouchi Y, Fukuda Y, Takahashi S, Ogura Y, et al. Lack of common NOD2 variants in Japanese patients with Crohn's disease. Gastroenterology 2002;123:86-91.

27 Arnott IDR, Nimmo ER, Drummond HE, Fennell J, Smith BR, MacKinlay E, et al. NOD2/CARD 15, TLR4 and CDI 4 mutations in Scottish and Irish Crohn's disease patients: evidence for genetic heterogeneity within Europe? Genes Immun 2004, Jun 10 (Epub ahead of print).

28 Helio $T$, Halme L, Lappalainen M, Fodstad H, Paavola-Sakki $P$, Turunen U, et al. CARD15/NOD2 gene variants are associated with familially occurring and complicated forms of Crohn's disease. Gut 2003;52:558-62.

29 Girardin SE, Boneca IG, Viala J, Chamaillard M, Labigne A, Thomas G, et al. Nod2 is a general sensor of peptidoglycan through muramyl dipeptide (MDP) detection. J Biol Chem 2003;278:8869-72.

30 Ogura Y, Inohara N, Benito A, Chen FF, Yamaoka S, Nunez G. Nod2, a Nod1 / Apaf-1 family member that is restricted to monocytes and activates NFkappaB. J Biol Chem 2001;276:4812-8.

31 Bonen DK, Ogura Y, Nicolae DL, Inohara N, Saab L, Tanabe T, et al. Crohn's disease-associated NOD2 variants share a signaling defect in response to lipopolysaccharide and peptidoglycan. Gastroenterology 2003;124:140-6.

32 Miceli-Richard C, Lesage S, Rybojad M, Prieur AM, Manouvrier-Hanu S, Hafner R, et al. CARD15 mutations in Blau syndrome. Nat Genet 2001;29:19-20.

33 Breban M, Said-Nahal R, Hugot JP, Miceli-Richard C. Familial and genetic aspects of spondyloarthropathy. Rheum Dis Clin North Am 2003:29:575-94.

34 Miceli-Richard C, Zouali H, Lesage S, Thomas G, Hugot JP, Said-Nahal R, et al. CARD15/NOD2 analyses in spondylarthropathy. Arthritis Rheum 2002;46:1405-6.

35 van der Paardt $M$, Crusius JB, de Koning MH, Murillo LS, van de Stadt RJ, Diikmans BA, et al. CARD1 5 gene mutations are not associated with ankylosing spondylitis. Genes Immun 2003;4:77-8.

36 Ferreiros-Vidal I, Amarelo J, Barros F, Carracedo A, Gomez-Reino JJ, Gonzalez A. Lack of association of ankylosing spondylitis with the most common NOD2 susceptibility alleles to Crohn's disease. J Rheumatol 2003:30:102-4.

37 D'Amato M. The Crohn's associated NOD2 3020InsC frameshift mutation does not confer susceptibility to ankylosing spondylitis. J Rheumatol 2002;29:2470-1.

38 Borgiani P, Vallo L, D'Apice MR, Giardina E, Pucci S, Capon F, et al. Exclusion of CARD15/NOD2 as a candidate susceptibility gene to psoriasis in the Italian population. Eur J Dermatol 2002;12:540-2.

39 Young C, Allen MH, Cuthbert A, Ameen M, Veal C, Leman J, et al. A Crohn's disease-associated insertion polymorphism (3020insC) in the NOD2 gene is not associated with psoriasis vulgaris, palmo-plantar pustular psoriasis or guttate psoriasis. Exp Dermatol 2003; 12:506-9.

40 Rahman P, Bartlett S, Siannis F, Pellett FJ, Farewell VT, Peddle L, et al. CARD15: a pleiotropic autoimmune gene that confers susceptibility to psoriatic arthritis. Am J Hum Genet 2003:73:677-81.

41 Giardina E, Novelli G, Costanzo A, Nistico S, Bulli C, Sinibaldi C, et al. Psoriatic arthritis and CARD15 gene polymorphisms: no evidence for association in the Italian population. J Invest Dermatol 2004;122:1106-7.

42 Cuthbert AP, Fisher SA, Mirza MM, King K, Hampe J, Croucher PJ, et al. The contribution of NOD2 gene mutations to the risk and site of disease in inflammatory bowel disease. Gastroenterology 2002;122:867-74.

43 Lesage S, Zouali H, Cezard JP, Colombel JF, Belaiche J, Almer S, et al. CARD15/NOD2 mutational analysis and genotype-phenotype correlation in 612 patients with inflammatory bowel disease. Am J Hum Genet 2002;70:845-57

44 Ahmad T, Armuzzi A, Bunce M, Mulcahy-Hawes K, Marshall SE, Orchard TR, et al. The molecular classification of the clinical manifestations of Crohn's disease. Gastroenterology 2002;122:854-66.

45 Abreu MT, Taylor KD, Lin YC, Hang T, Gaiennie J, Landers CJ, et al. Mutations in NOD2 are associated with fibrostenosing disease in patients with Crohn's disease. Gastroenterology 2002;123:679-88.

46 Peeters H, Vander Cruyssen B, Laukens D, Coucke P, Marichal D, Van Den Berghe $M$, et al. Radiological sacroiliitis, a hallmark of spondylitis, is linked with CARD154 gene polymorphisms in patients with Crohn's disease. Ann Rheum Dis 2004;63:1131-4.

47 Dougados M, van der Linden S, Juhlin R, Huitfeldt B, Amor B, Calin A, et al. The European Spondylarthropathy Study Group preliminary criteria for the classification of spondylarthropathy. Arthritis Rheum 1991;34:1218-27.

48 van der Linden SM, Khan MA. The risk of ankylosing spondylitis in HLA-B27 positive individuals: a reappraisal. J Rheumatol 1984;11:727-8. 
49 Mielants H, Veys EM, Cuvelier C, Goemaere S, De Clercq L, Schatteman L, et al. The evolution of spondyloarthropathies in relation to gut histology. III. Relation between gut and joint. J Rheumatol 1995;22:2279-84.

50 Mielants H, Veys EM, De Vos M, Cuvelier C, Goemaere S, De Clercq L, et al. The evolution of spondyloarthropathies in relation to gut histology. I. Clinical aspects. J Rheumatol 1995;22:2266-72.

51 Cuvelier C, Barbatis C, Mielants H, De Vos M, Roels H, Veys E. Histopathology of intestinal inflammation related to reactive arthritis. Gut 1987;28:394-401.

52 Altomonte L, Zoli A, Veneziani A, Mirone L, Santacesaria G, Chiarelli C, et al. Clinically silent inflammatory gut lesions in undifferentiated spondyloarthropathies. Clin Rheumatol 1994;13:565-70.
53 Terasaki PI, McClelland JD. Microdroplet assay of human serum cytotoxin. Nature 1964;204:998-1000.

54 Crane AM, Bradbury L, van Heel DA, McGovern DP, Brophy S, Rubin K, et al. Role of NOD2 variants in spondylarthritis. Arthritis Rheum 2002;46: 1629-33.

55 Salmi M, Jalkanen S. Human leukocyte subpopulations from inflamed gut bind to joint vasculature using distinct sets of adhesion molecules. J Immunol $2001 ; 166: 4650-7$

56 Gutierrez O, Pipaon C, Inohara N, Fontalba A, Ogura Y, Prosper F, et al. Induction of Nod2 in myelomonocytic and intestinal epithelial cells via nuclear factor-kappa B activation. J Biol Chem 2002;277:41701-5.

\section{Get published within days of acceptance with ARD}

We are delighted to announce that the Annals of the Rheumatic Diseases launched a "publish ahead of print" programme in February 2004. Selected papers are fast tracked and published online months before they appear in the print journal.

Papers of major significance to the international rheumatology community are published within days of acceptance. The first published article is the raw accepted manuscript; edited and typeset versions are also published as soon as they are available.

In addition to being available on ARD Online, the publish ahead of print articles are searchable through PubMed/ Medline-establishing primacy for your work. They are linked from the ARD Online home page.

To take advantage of this "publish ahead of print" programme submit your papers to the Annals of the Rheumatic Diseases using our online submission and review system Bench $>$ Press (http://submit-ard.bmijournals. com). For further information contact ARD@bmigroup.com. 